\title{
DT\#47003 QA:NA 2/28/06 \\ MODELING COUPLED PROCESSES OF MULTIPHASE FLOW AND HEAT TRANSFER IN UNSATURATED FRACTURED ROCK
}

\author{
Yu-Shu Wu ${ }^{1}$, S. Mukhopadhyay ${ }^{1}$, K. Zhang ${ }^{1}$, and G. S. Bodvarsson ${ }^{1}$ \\ ${ }^{1}$ Earth Sciences Division, Lawrence Berkeley National Laboratory, MS 90-1116 \\ Berkeley CA94720, USA
}

\begin{abstract}
A mountain-scale, thermal-hydrologic (TH) numerical model is developed for investigating unsaturated flow behavior in response to decay heat from the radioactive waste repository at Yucca Mountain, Nevada, USA. The TH model, consisting of three-dimensional (3-D) representations of the unsaturated zone, is based on the current repository design, drift layout, and thermal loading scenario under estimated current and future climate conditions. More specifically, the TH model implements the current geological framework and hydrogeological conceptual models, and incorporates the most updated, best-estimated input parameters. This mountain-scale TH model simulates the coupled TH processes related to mountain-scale multiphase fluid flow, and evaluates the impact of radioactive waste heat on the hydrogeological system, including thermally perturbed liquid saturation, gas- and liquid-phase fluxes, and water and rock temperature elevations, as well as the changes in water flux driven by evaporation/condensation processes and drainage between drifts. For a better description of the ambient geothermal condition of the unsaturated zone system, the TH model is first calibrated against measured borehole temperature data. The ambient temperature calibration provides the necessary surface and water table boundary as well as initial conditions. Then, the TH model is used to obtain scientific understanding of TH processes in the Yucca Mountain unsaturated zone under the designed schedule of repository thermal load.
\end{abstract}

\section{INTRODUCTION}

Since the 1980s, the 500-700 m thick unsaturated zone (UZ) of Yucca Mountain, Nevada, USA, has been extensively investigated as a potential subsurface repository for storing high-level radioactive wastes. While site characterization has been carried out mostly for analyzing unsaturated flow and tracer transport under ambient conditions $(\mathrm{Wu}$ et al., 1999; Wu et al. 2002), the inherent nature of nonisothermal flow and transport processes, created by repository heating from radioactive decay, has also motivated many research efforts to understand coupled thermal-hydrological (TH) behavior and its impact on repository performance within the UZ. In particular, significant progress has been made in quantitative TH modeling studies at Yucca Mountain (Haukwa et al. 1999; Haukwa et al. 2003; Buscheck et al. 2002). 
The need to quantitatively characterize TH processes occurring in the UZ geological formation at Yucca Mountain has posed a tremendous challenge for investigators as well as motivated a continual effort to develop and apply different scale fluid and heat flow models (Tsang and Pruess, 1987; Pruess et al., 1990a; 1990b; Buscheck et al., 1994; Haukwa et al., 1999; 2003; Buscheck et al., 2002; Mukhophadhyay and Tsang, 2002; 2003). These numerical models have played a crucial role in understanding coupled fluid and heat flow as well as in assessing how TH conditions affect various aspects of the overall UZ waste disposal system. These modeling investigations are complementary to laboratory studies and field heater experiments to study physical processes on the temporal and spatial scales relevant to understanding nuclear-waste-repository performance in a geological formation.

Despite the significant advances made in modeling TH processes within the UZ repository system at Yucca Mountain, previous studies have been (for the most part) limited to small spatial- and temporal-scale analyses. For large, mountain-scale multidimensional modeling exercises, the effective continuum model (ECM), rather than the more rigorous dual-continuum approach, has often been resorted to in these studies (Wu et al., 1995; Haukwa et al., 1999). This choice primarily results from the numerical difficulty and computational intensity involved in solving highly nonlinear coupled twophase fluid flow and heat transfer under boiling conditions in unsaturated fractured rock. In recent years, mountain-scale TH models implementing the dual-permeability approach have been developed (Haukwa et al., 2003) with a two-dimensional model. Mountainscale $\mathrm{TH}$ processes have also been investigated with the multiscale thermal-hydrologic model (Buscheck et al., 2002). In general, there has been the lack of modeling effort using the 3-D, large spatial and temporal scale, fully coupled TH analyses in Yucca Mountain fractured rock using the dual-permeability modeling (DKM) approach. It is in this context that the 3-D, mountain-scale, fully coupled TH model is presented in this paper.

This paper presents the results of our continuing effort to develop a representative mountain-scale fully coupled TH model that could characterize TH processes in the UZ repository under thermal load (Wu et al., 2005). More specifically, the TH model implements the current geological framework and hydrogeological conceptual model, and incorporates the updated input parameters (Wu et al., 2004). Using the rigorous dualpermeability modeling approach, the TH model described in this paper implements a full 3-D representation within the repository and UZ system, which explicitly includes every waste emplacement drift of the repository in which flow and heat transfer processes along drifts are approximated as porous-medium phenomena without considering the details of air dynamics within the tunnel. For a better understanding of the ambient geothermal conditions of the UZ system, the TH model is first calibrated against measured borehole temperature data under the ambient geothermal condition, providing the needed surface and water table boundary as well as initial conditions for the TH model.

In this paper, the 3-D mountain-scale TH model is presented to study the TH perturbation at Yucca Mountain. The objective is to investigate spatial and temporal perturbation and its impact on temperature, matrix and fracture liquid saturation, and percolation fluxes in the mountain caused by repository heating. Distribution of 
infiltration fluxes at the top of the mountain and thermal loading at the repository are the two factors that primarily control the evolution of TH processes in the mountain. Changes in the infiltration flux resulting from climate changes have been accounted for in this paper by considering a time-dependent net infiltration map with a three-step increase, representing present-day, monsoon, and glacial climates. The impact of repository thermal loading on $\mathrm{TH}$ processes in the mountain has been investigated in this study by considering two separate thermal loading scenarios with or without ventilation along repository drifts.

\section{HYDROGEOLOGICAL AND NUMERICAL MODELS}

The geological model used for developing the TH model numerical grid is based on the current geological framework model for Yucca Mountain (BSC, 2004a). In this geological model, the UZ geological system is organized into layered hydrogeologic units, based primarily on the degree of welding (Montazer and Wilson, 1984), the Tiva Canyon welded (TCw) hydrogeologic unit, the Paintbrush nonwelded unit (PTn), the Topopah Spring welded (TSw) unit, the Calico Hills nonwelded unit $(\mathrm{CHn})$, and the Crater Flat undifferentiated (CFu) units.

Shown in Figure 1 is the 3-D numerical grid used in this study for the mountain-scale TH model, in which the 3-D UZ model domain is represented using an irregular, unstructured, control-volume grid (Pan et al., 2001). The 3-D TH model grid, as shown in Figure 1 in its plan view, covers approximately $20 \mathrm{~km}^{2}$ of the area, uses a refined mesh in the vicinity of the emplacement drifts, and incorporates every repository drift explicitly by taking into account their orientations, lengths, elevations, and spacing. Specifically, a grid spacing of $81 \mathrm{~m}$ is used in the direction perpendicular to drifts, the same as the designed drift spacing. At the repository horizon, a segment of a $5.5 \mathrm{~m}$ diameter cylinder is inserted and used to represent waste emplacement drifts for thermalloading TH studies. The 3-D TH model grid consists of 86,440 gridblocks and 343,520 connections between the gridblocks in a dual-permeability mesh.

The modeling approach used in this work for handling multiphase flow and heat transfer through fractured rock is based on the dual-permeability method. This approach considers global fluid and heat flow occurring not only between fractures but also between matrix blocks. In this approach, one rock-volume domain is represented by two overlapping fracture and matrix continua. The fracture-matrix fluid flow is evaluated using the quasi-steady-state approximation (Warren and Root, 1963), which has been extended for estimating local energy exchange terms between fracture and matrix systems.

The actual simulation of physical processes associated with fluid and heat flow in fractured tuffs are carried out using the TOUGH2 code (Pruess et al., 1999). Fluid flow and heat-transfer processes in a two-phase, air-water system of fractured rock are described separately using a doublet of governing equations, respectively, for the two fracture and matrix continua. Two-phase flow is described by the multiphase extension of Darcy's law, whereas relative permeability and capillary functions of both fractures and 
matrix are assumed to follow the model of van Genuchten (1980). Heat-transfer mechanisms in the two-phase system include conduction, convection, and radiation, associated with latent heat caused by phase changes in vaporization (boiling) and condensation in the fractured rock. The integral finite-difference scheme is used for spatial discretization, and time discretization is carried out with a backward, first-order, finitedifference scheme. The resulting discrete nonlinear algebraic equations for describing mass and energy conservation are written in a residual form and solved using the Newton/Raphson iteration scheme.

In the TH model, input parameters for fracture and matrix rock as well as fluid properties were estimated in several studies (Wu et al., 2004; Ghezzehei and Liu, 2004; Pan and Liu, 2004). In addition, thermal properties, including grain density, wet and dry thermal conductivity, and grain-specific heat for each model grid layer, are provided in $\mathrm{Wu}$ et al. (2004). Temperature-dependent fluid properties, such as fluid density, viscosity, and specific enthalpy, are incorporated in the formulation of the TOUGH2 code.

The repository thermal load and its schedule are shown in Figure 2, based on an average initial thermal line load of $1.45 \mathrm{~kW} / \mathrm{m}$, along each emplacement drift for the radioactive heat source, decreasing with time as a result of radioactive decay. A basecase thermal load scenario is that heat is removal by forced ventilation, for which, during the first 50 years after waste emplacement, $86.3 \%$ of the heat is assumed to be removed by ventilation. After the first 50 years, the full thermal load becomes applicable (i.e., no difference in thermal load with the no-ventilation case). The no ventilation case is used for sensitivity analysis in this paper. Note that the actual process of ventilation is not modeled in this study, though the heat-generation rate is reduced to account for heat removal by ventilation.

The 3-D TH model uses the ground surface of Yucca Mountain (or the tuffalluvium contact in areas of significant alluvial cover) as the top model boundary, and the water table is treated as the bottom model boundary. Both the top and bottom boundaries of the models are specified as constant over time, but spatially varying temperatures and gas pressures. The water table is relatively flat, increasing its elevation only in the north. At the southern part of the model domain, the water table is about $730 \mathrm{~m}$ above sea level (masl). Gas pressures are estimated as $92 \mathrm{kPa}$ at an elevation of 730 masl. The surface gas pressures are then determined by running the TOUGH2 software to steady state under given temperature, bottom pressure, and surface-infiltration conditions. In addition, at the surface boundary, the TH model uses three net infiltration rates as a step function of time for surface-water-recharge boundary conditions. The three averaged net infiltration rates consist of one present-day and two future (monsoon and glacial infiltration, respectively) scenarios, determined by studies of modern and future climates (BSC, 2004b) for their spatial distributions. The actual timing of the three TH-model infiltration rates are shown in Table 1, indicating average values over the model domain for three time periods: present ( 0 to 600 years), monsoon (600 to 2,000 years), and glacial transition (2,000 years and beyond). 


\section{RESULTS AND DISCUSSION}

In this section, results are presented from the 3-D mountain-scale TH model to provide predictive information about the responses of the $\mathrm{UZ}$ system under thermal load (Wu et al. 2005). More specifically, the simulation results presented here are compared for the impact of ventilation on mountain-scale TH processes.

\subsection{Tememperature}

Figures $3(3 \mathrm{~A}$ and $3 \mathrm{~B})$ and $4(4 \mathrm{~A}$ and $4 \mathrm{~B})$ show contours of temperatures simulated along the repository horizon of the 3-D numerical grid, respectively, at 100 years and 1,000 years for the two scenarios with and without ventilation. The simulated temperatures at repository horizon after 100 years of repository thermal load with ventilation, as shown in Figures $3 \mathrm{~A}$ and $3 \mathrm{~B}$, indicate a large difference in simulated temperature contours from these two thermal loading scenarios with and without ventilation. Figure 3B shows that without ventilation, a boiling condition at the ambient atmospheric pressure $\left(\sim 96^{\circ} \mathrm{C}\right)$ is reached in most of the repository blocks, while only several isolated rock blocks may reach the boiling condition with ventilation. (Note that temperatures shown in these figures are for the rock surrounding the drift and not for the drift itself, where boiling temperatures are reached within most drifts with the ventilation case in 100 years.)

At a longer time of 1,000 years, as shown in Figures $4 \mathrm{~A}$ and $4 \mathrm{~B}$, the boiling condition still lasts along the central portion of drifts away from the repository layout boundary for both scenarios. Note that boiling or near-boiling zones for the nonventilation case (Figure 4B) is larger than in the ventilation scenario (Figure 4A). However, the difference becomes smaller when compared with Figures 3A and 3B for 100 years. This indicates that the impact of 50-year ventilation gets progressively weaker as time goes on. Note that after 1,000 years, the thermal effect of repository heating starts decreasing (Figure 2).

Figures $5 \mathrm{~A}$ and $5 \mathrm{~B}$ show the vertical spatial variations at 5,000 years in simulated temperatures along the NS cross section of the 3-D model (Figure 1). The highest temperatures within the repository horizon, at this time, are only about $60^{\circ} \mathrm{C}$. At these later times, the two scenarios become almost identical.

\subsection{Percolation Flux}

One of the primary utilities of the mountain-scale TH model is to analyze the impact of repository heating on the spatial distribution of percolation fluxes. Using the 3$D$ numerical grid, the ambient vertical fracture fluxes in a horizontal cross section at the repository horizon are shown in Figure 6. The ambient percolation flux distribution of Figure $6 \mathrm{~A}$ is based on the present-day infiltration scenario (see Table 1). In the central part of the repository (to the left of the Drillhole Wash Fault), the percolation fluxes in the fractures are on the order of 7-9 mm/year under ambient conditions. Compare Figure $6 \mathrm{~A}$ with Figure 6B, which shows the contribution of vertical fracture fluxes at 500 years 
in the same cross section as that of Figure 6A. Percolation fluxes significantly increase in the repository horizon, particularly in the areas directly above the drifts. Again, water displaced from the rock matrix by boiling condenses above the dryout zone and drains through the fractures. As a result, percolation fluxes in the fractures above the drift increase considerably during and immediately after the boiling periods at 500 years with repository thermal loading under ventilation conditions.

Percolation flux distribution under repository thermal loading without ventilation is more clearly seen in Figure 6C. In this thermal loading scenario, the percolation flux above the repository (in the condensate zone) is twice the ambient infiltration, resulting from displacement of matrix pore water by boiling. At the same time, model results show that fracture fluxes just below the repository are considerably smaller. Because of the capillary barrier effects of the emplacement drifts, water cannot enter the drifts and is diverted through the pillar region, resulting in a relatively dry region below the drift.

\section{SUMMARY AND CONCLUSIONS}

This paper describes a 3-D, mountain-scale TH model and its application to assess thermal and hydrological responses to repository heat release at Yucca Mountain. The TH model numerically simulates the impact of nuclear-waste heat release on the natural hydrogeological system, including a representation of heat-driven processes occurring at the repository drifts (as well as in the far field). The mountain-scale TH model provides a predictive tool for thermally affected liquid saturation, gas- and liquid-phase fluxes, and water and rock temperature.

The 3-D mountain-scale TH model in this paper uses the dual-permeability modeling approach for handling fracture-matrix interaction. The 3-D TH model grid, though having relatively coarse grid spacing, incorporates every repository drift explicitly by taking into account orientations, lengths, elevations, and spacing of the repository drifts, such that adjacent drifts are represented one-to-one by adjacent gridblocks $81 \mathrm{~m}$ wide. To account for future climates and their impact on $\mathrm{TH}$ behavior at the repository, the mountain-scale TH model implements three infiltration rates over three time periods, stepped up sequentially over the modeled period: present-day (0-600 years), monsoon (600-2,000 years), and glacial transition (2,000 and beyond). Initial and boundary conditions are obtained by calibration to observed geothermal gradients at Yucca Mountain. Representative repository thermal load at Yucca Mountain is used as the source of heating. Two thermal loading scenarios are investigated. In the first scenario, no heat is removed by ventilation. In the second scenario, approximately $86 \%$ of the repository thermal load is removed by forced ventilation during the first 50 years after waste emplacement.

Mountain-scale TH model results demonstrate that when heat is removed by ventilation, rock temperatures around the drift barely reach boiling (although temperatures within the drifts may be above boiling). However, the enhancement in fracture percolation fluxes during the thermal period near the repository drifts is significant, but relatively smaller compared to the no-ventilation thermal loading 
scenario. Overall, the impact of ventilation on the evolution of TH processes at Yucca Mountain is limited in the vicinity of the drifts and during the first few hundred years or so. Elsewhere in the mountain and at other times, the $\mathrm{TH}$ conditions are comparable between the two thermal loading scenarios.

The mountain-scale TH models in this paper provide a contemporary understanding of the $\mathrm{TH}$ processes likely to occur in the mountain. These models not only provide useful predictions about the $\mathrm{TH}$ conditions in the mountain, but also provide the considerations for safe design of the repository. As a result, the reliability of these models is an important issue. There are, of course, certain limitations to the mountain-scale models, and one significant limitation to the mountain-scale $\mathrm{TH}$ model in this paper is that it does not incorporate small- and large-scale heterogeneities within each stratigraphic unit. In addition, repository heating causes chemical and mechanical changes in the rock. These chemical and mechanical changes in turn alter the hydrological properties of the rock, which have the potential to alter the TH response of the rock. These dynamic changes in the rock concurrent with repository heating have not been considered in this paper. Future modeling efforts may be directed towards resolving some of these issues.

\section{ACKNOWLEDGMENTS}

This work was supported by the Director, Office of Civilian Radioactive Waste Management, U.S. Department of Energy, through Memorandum Purchase Order EA9013MC5X between Bechtel SAIC Company, LLC, and the Ernest Orlando Lawrence Berkeley National Laboratory (Berkeley Lab). The support is provided to. Berkeley Lab through the U.S. Department of Energy Contract No. DE-AC03-76SF00098. The reviews and comments of Guoxiang Zhang and Dan Hawkes from Berkeley Lab are greatly appreciated.

\section{REFERENCES}

BSC, Geologic Framework Model (GFM2000), MDL-NBS-GS-000002 REV 02, Bechtel SAIC Company, Las Vegas, Nevada, 2004a.

BSC, Future Climate Analysis, ANL-NBS-GS-000008 REV 01, Bechtel SAIC Company, Las .Vegas, Nevada, 2004b.

Buscheck, T.A., Rosenberg, N.D., Gansemer, J., and Sun, Y., Thermohydrologic

Behavior at an Underground Nuclear Waste Repository, Water Resources Research, 38(3), pp. 1-19, 2002.

Buscheck, T.A., Nitao, J.J., and Saterlie, S.F., Evaluation of Thermo-Hydrological

Performance in Support of the Thermal Loading Systems Study, High Level

Radioactive Waste Management, Proceedings of the Fifth Annual International

Conference, Las Vegas, Nevada, May 22-26, 1994. 2, pp. 592-610, 1994.

Ghezzehei, T. A. and H. H. Liu, Calibrated Properties Model, MDL-NBS-HS-000003

REV 02, Bechtel SAIC Company, Las Vegas, Nevada, 2004. 
Haukwa, C.B., Wu, Y-S., and Bodvarsson, G.S., Modeling Thermal-Hydrological Response of the Unsaturated Zone at Yucca Mountain, Nevada, to Thermal Load at a Potential Repository, Journal of Contaminant Hydrology, 62-63, pp. 529-552, 2003.

Haukwa, C.B., Wu, Y-S., and Bodvarsson, G.S., Thermal Loading Studies Using the Yucca Mountain Unsaturated Zone Model, Journal of Contaminant Hydrology, 38(1-3), pp. 217-255, 1999.

Montazer, P. and Wilson, W.E., Conceptual Hydrologic Model of Flow in the Unsaturated Zone, Yucca Mountain, Nevada, Water-Resources Investigations Report 84-4345, U.S. Geological Survey, Lakewood, Colorado, 1984.

Mukhophadhyay, S. and Tsang, Y.W., Uncertainties in Coupled Thermal-Hydrological Processes Associated with the Drift Scale Test at Yucca Mountain, Nevada, Journal of Contaminant Hydrology, 62-63, pp. 595-612, 2003.

Mukhophadhyay, S. and Tsang, Y.W., Understanding the Anomalous Temperature Data from the Large Block Test at Yucca Mountain, Nevada, Water Resources Research, 38(10), pp. 28-1-28-12, 2002.

Pan, L. and Liu, H.H., Analysis of Hydrologic Properties Data, ANL-NBS-HS-000042 REV 00, Bechtel SAIC Company, Las Vegas, Nevada, 2004.

Pan, L., Hinds, J., Haukwa, C.B., Wu, Y-S., and Bodvarsson, G.S., WinGridder - An interactive grid generator for TOUGH, Version 1.0 User's Manual, LBNL-42957, Lawrence Berkeley Laboratory, Berkeley, California, 2001.

Pruess, K., Oldenburg, C., and Moridis, G., TOUGH2 User's Guide, Version 2.0, LBNL43134, Lawrence Berkeley National Laboratory, Berkeley, California, 1999.

Pruess, K., Wang, J.S.Y., and Tsang, Y.W., On Thermohydrologic Conditions Near HighLevel Nuclear Wastes Emplaced in Partially Saturated Fractured Tuff, 1. Simulation Studies with Explicit Consideration of Fracture Effects, Water Resources Research, 26(6), pp. 1235-1248, 1990a.

Pruess, K., Wang, J.S.Y., and Tsang, Y.W., On Thermohydrologic Conditions Near HighLevel Nuclear Wastes Emplaced in Partially Saturated Fractured Tuff, 2. Effective Continuum Approximation, Water Resources Research, 26(6), pp. 1249-1261, $1990 \mathrm{~b}$.

Tsang, Y.W. and Pruess, K., A Study of Thermally Induced Convection near a HighLevel Nuclear Waste Repository in Partially Saturated Fractured Tuff, Water Resources Research, 23(10), pp. 1958-1966, 1987.

van Genuchten, M.T., A Closed-Form Equation for Predicting the Hydraulic Conductivity of Unsaturated Soils, Soil Science Society of America Journal, 44(5), pp. 892-898, 1980.

Warren, J.E. and Root, P.J., The Behavior of Naturally Fractured Reservoirs, Society of Petroleum Engineers Journal, 3(3), pp. 245-255, 1963.

Wu, Y.S, Mukhopadhyay, S., Zhang, K., Sonnenthal, E.L., Zhang, G., and Rutqvist, J., Mountain-Scale Coupled Processes (TH/THC/THM) Models, MDL-NBS-HS000007 REV03, Lawrence Berkeley National Laboratory, Berkeley, California, Bechtel SAIC Company, Las Vegas, NV, 2005.

Wu, Y.S., G. Lu, K. Zhang, G. Zhang, H.H. Liu, T. Xu, and E.L. Sonnenthal, UZ Flow Models and Submodels, Research Report (AMR), MDL-NBS-HS-000006, REV02, 
Lawrence Berkeley National Laboratory, Berkeley, California, Bechtel SAIC

Company, Las Vegas, Nevada, 2004.

Wu, Y. S., Pan, L., Zhang, W., and Bodvarsson, G.S., Characterization of Flow and

Transport Processes within the Unsaturated Zone of Yucca Mountain, Nevada,

Under Current and Future Climates, Journal of Contaminant Hydrology, 54(3-4),

pp. 215-247, 2002.

Wu, Y.S., Haukwa, C., and Bodvarsson, G.S., A Site-Scale Model for Fluid and Heat

Flow in the Unsaturated Zone of Yucca Mountain, Nevada, Journal of Contaminant Hydrology, 38(1-3), pp. 185-215, 1999.

Wu, Y. S., Chen, G., and Bodvarsson, G.S., Preliminary Analysis of Effects of Thermal Loading on Gas and Heat Flow within the Framework of LBNL/USGS Site-Scale Model, LBL-37729: UC-814, Lawrence Berkeley National Laboratory, Berkeley, California, 1995.

TABLE 1. Averaged infiltration rates $(\mathrm{mm} / \mathrm{yr})$ and time period over the TH model domain

\begin{tabular}{|c|c|c|}
\hline Scenario & Time Period & $\begin{array}{c}\text { Mean Infiltration } \\
(\mathbf{m m} / \mathbf{y r})\end{array}$ \\
\hline Present-Day/Modern & $0-600$ years & $3.6^{\prime}$ \\
\hline Monsoon & $600-2,000$ years & 10.4 \\
\hline Glacial Transition & 2,000 and beyond & 16.1 \\
\hline
\end{tabular}




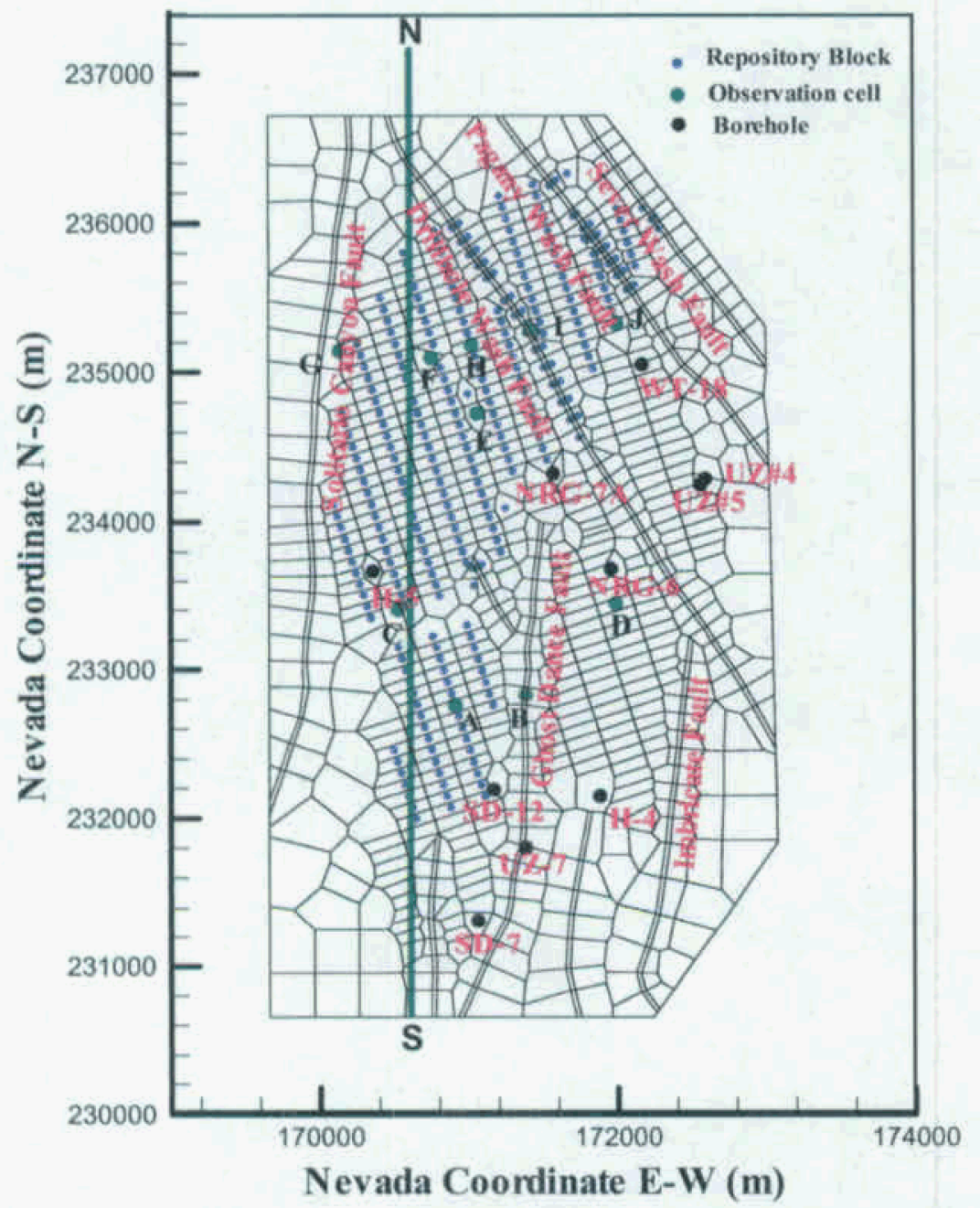

FIGURE 1. Plan view of the three-dimensional TH model grid showing the model domain, faults incorporated, several borehole locations, and TH model boundaries 


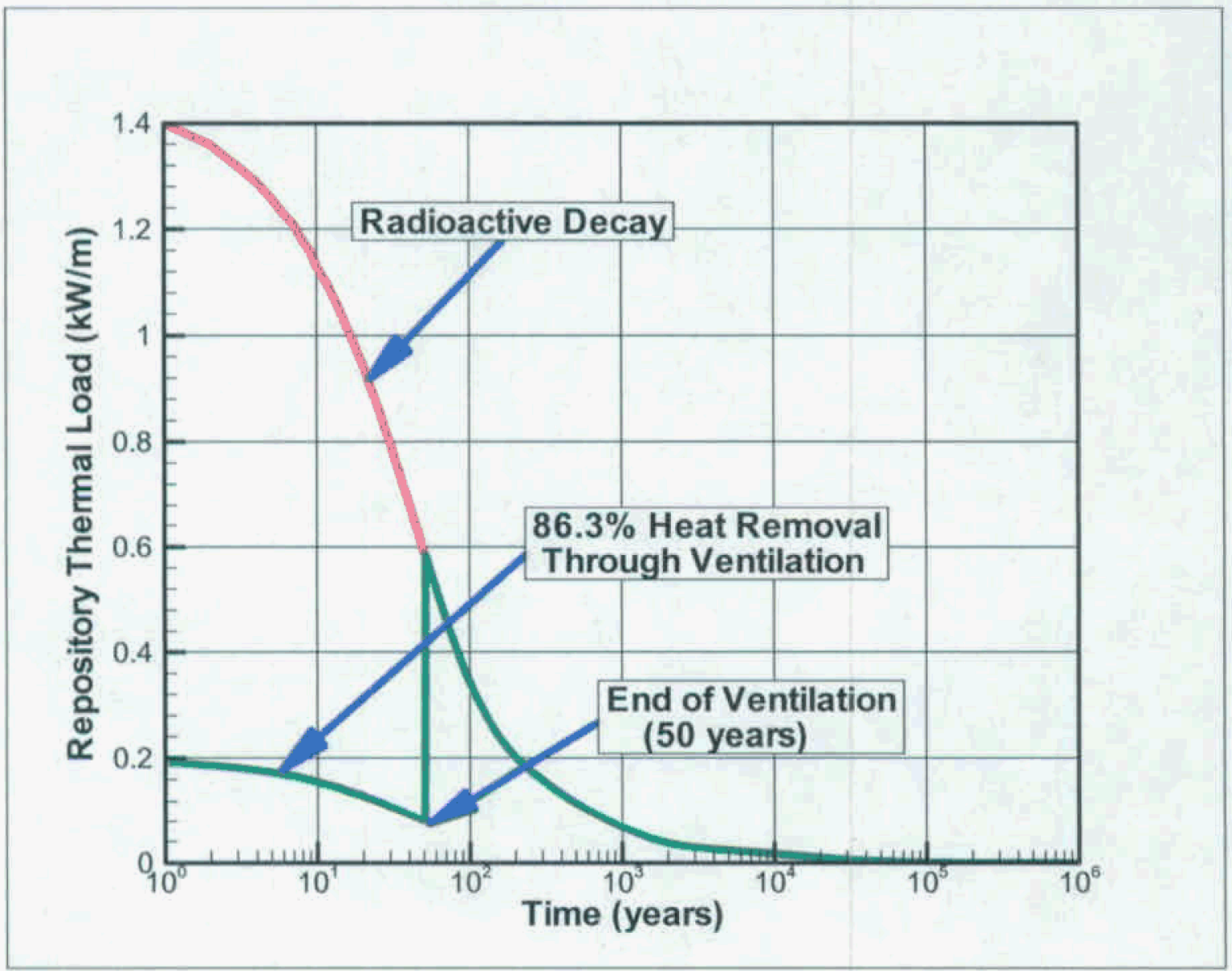

FIGURE 2. Radioactive heat decay curve for an initial thermal load of $1.45 \mathrm{~kW} / \mathrm{m}$. showing the thermal load when $86.3 \%$ of the heat is removed by ventilation during the first 50 years 


\section{Temperature Distribution at Repository Horizon (100 years)}

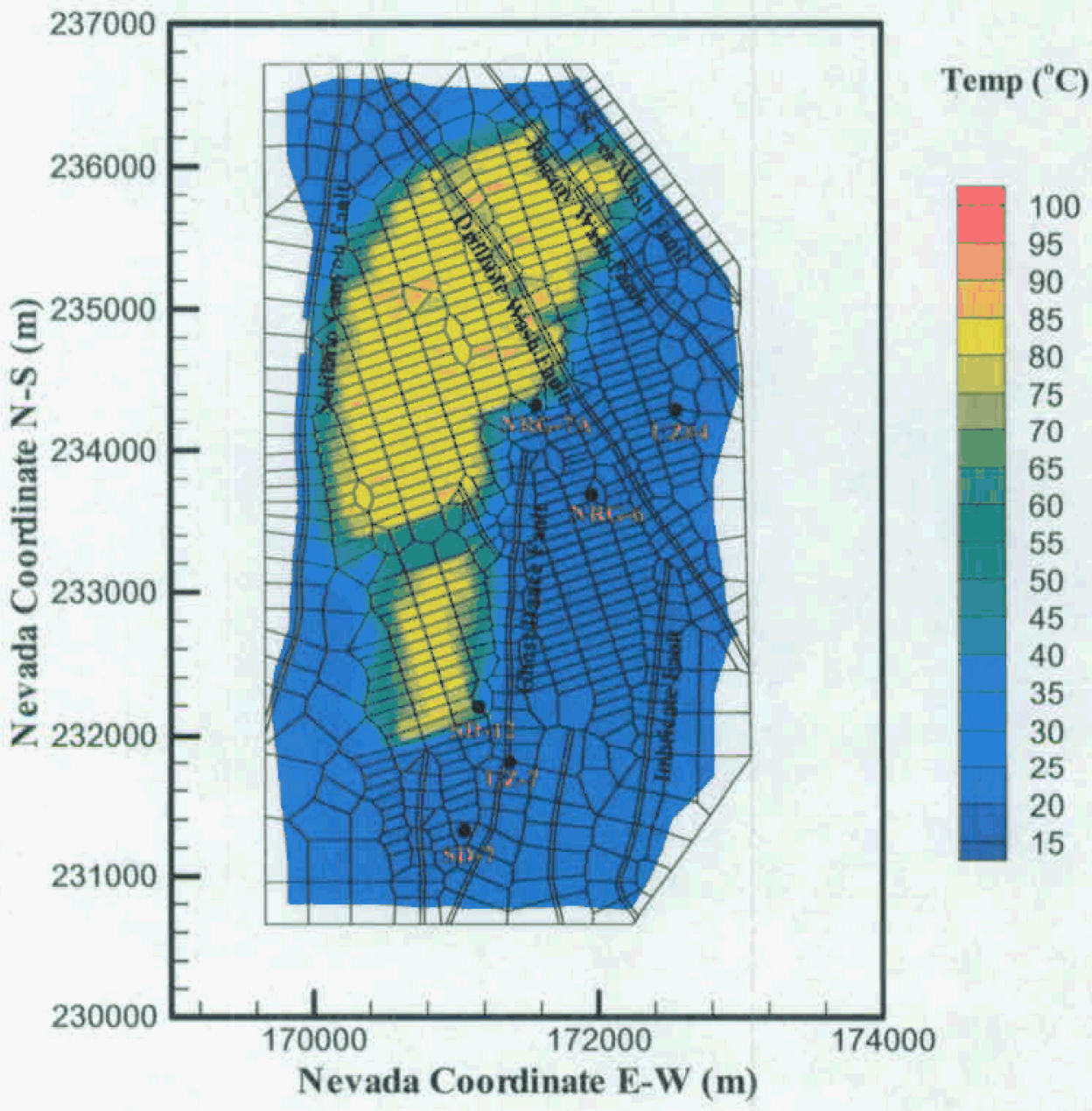

FIGURE 3A. Model-predicted rock temperature distribution at repository horizon at time of 100 years after nuclear waste emplacement (the base-case model with ventilation). 


\section{Temperature Distribution at Repository Horizon}

(100 years, nv)

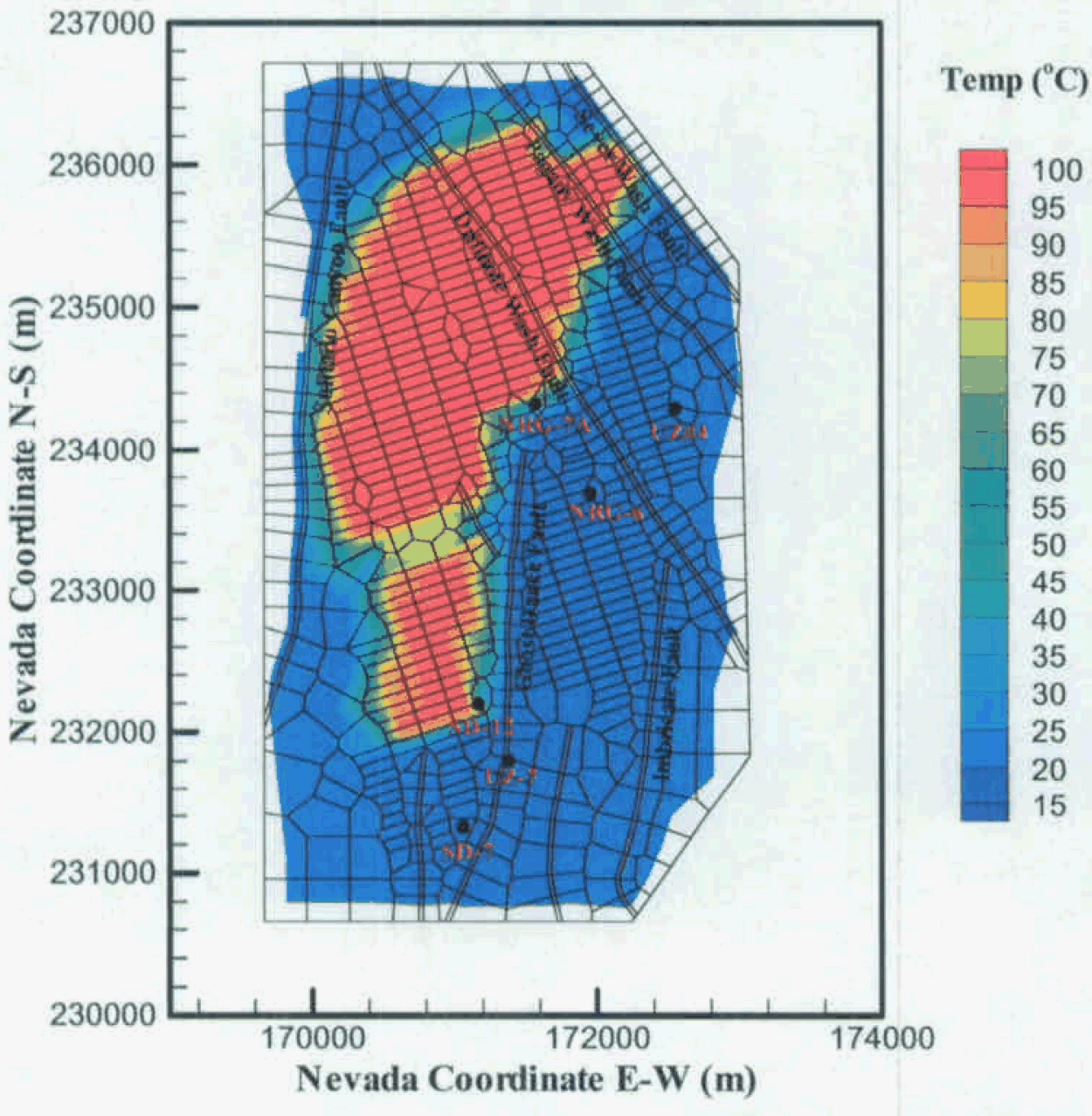

FIGURE 3B. Rock temperature distribution at the repository horizon 100 years after waste emplacement as predicted by the 3-D TH model 


\section{Temperature Distribution at Repository Horizon (1000 year, v)}

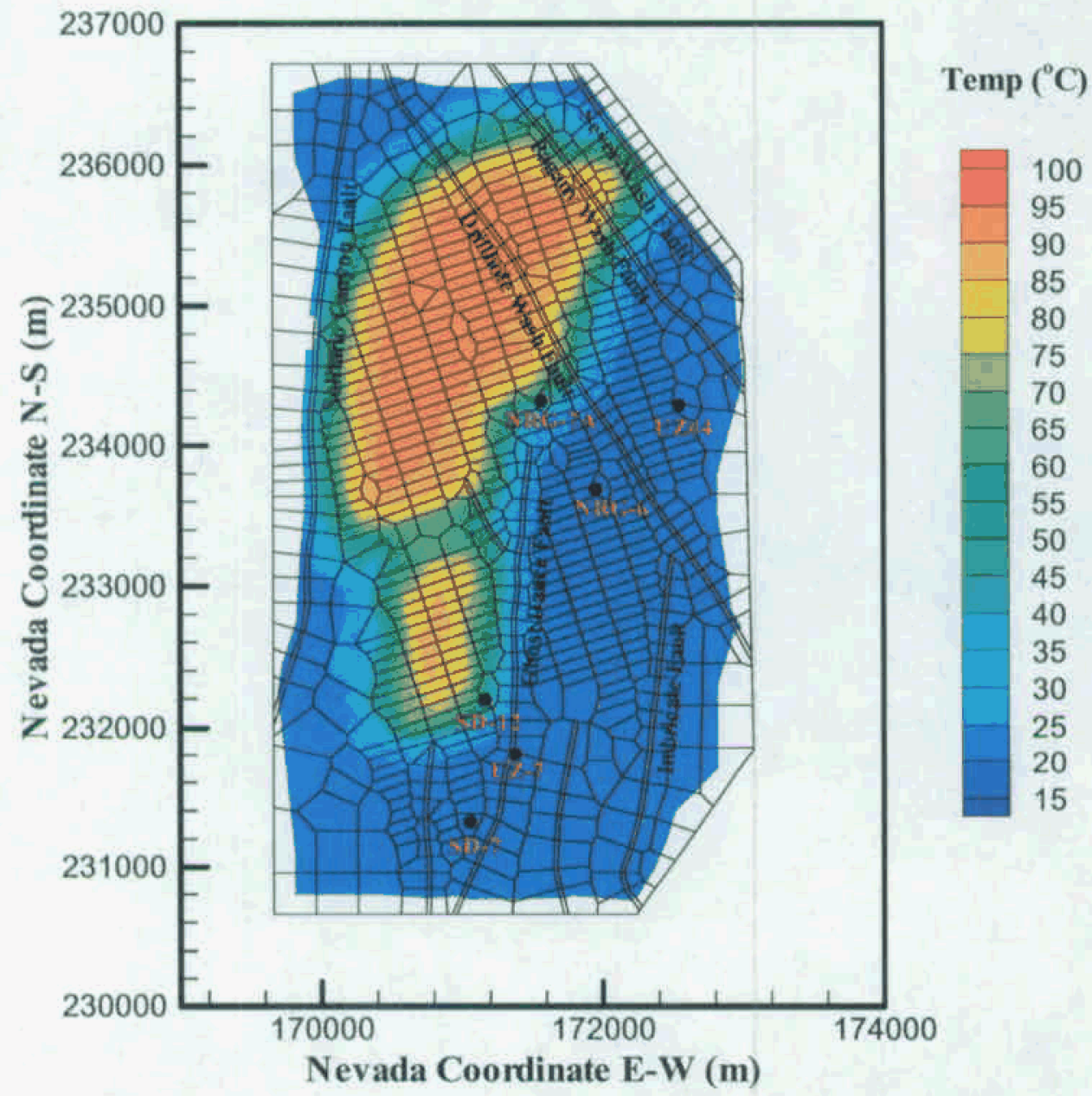

FIGURE 4A. Model-predicted rock temperature distribution at repository horizon at 1,000 years after nuclear waste emplacement (the base-case model with ventilation) 


\section{Temperature Distribution at Repository Horizon (1000 year, nv)}

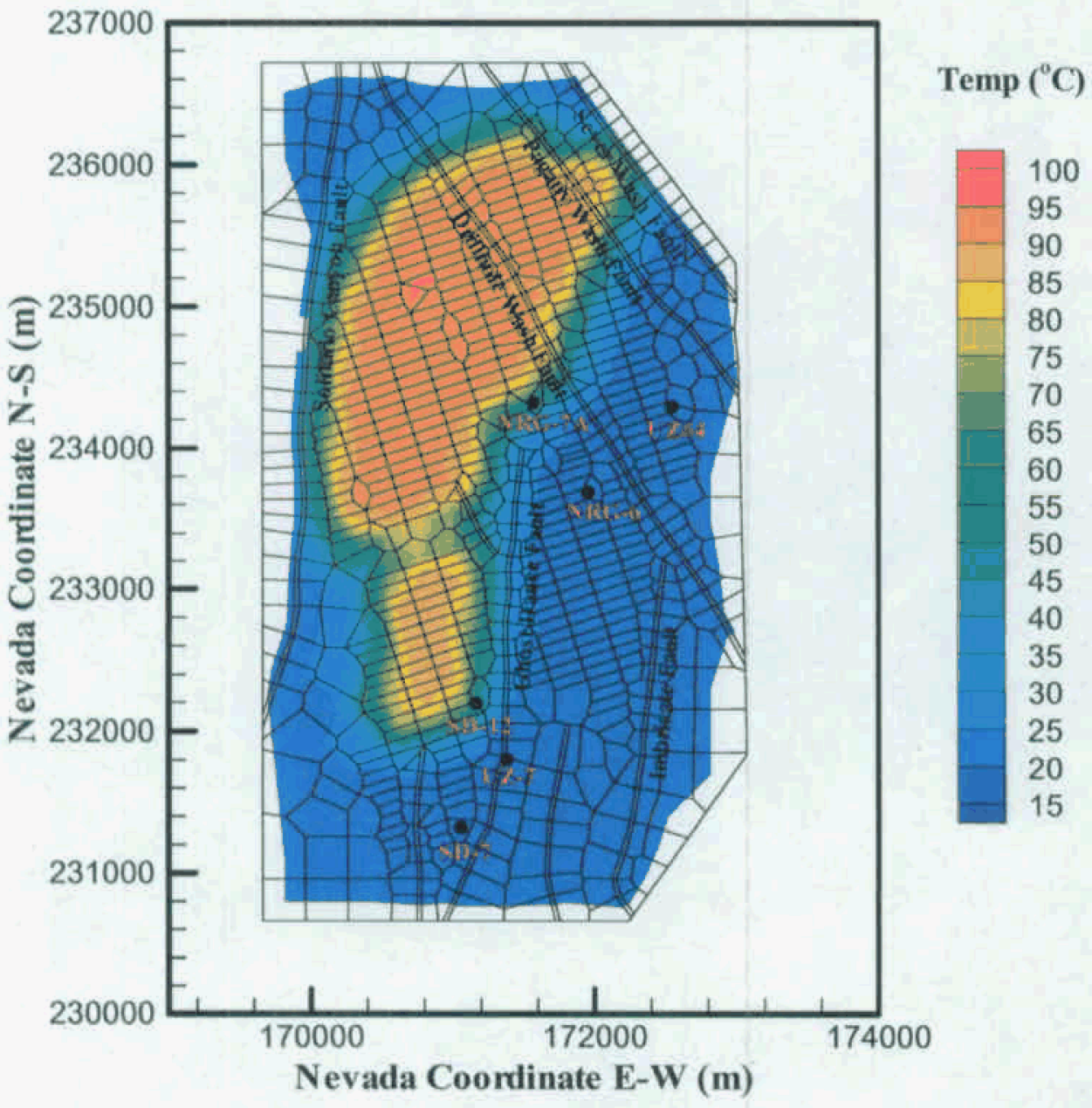

FIGURE 4B. Rock temperature distribution at the repository horizon 1,000 years after waste emplacement as predicted by the 3 -D TH model 


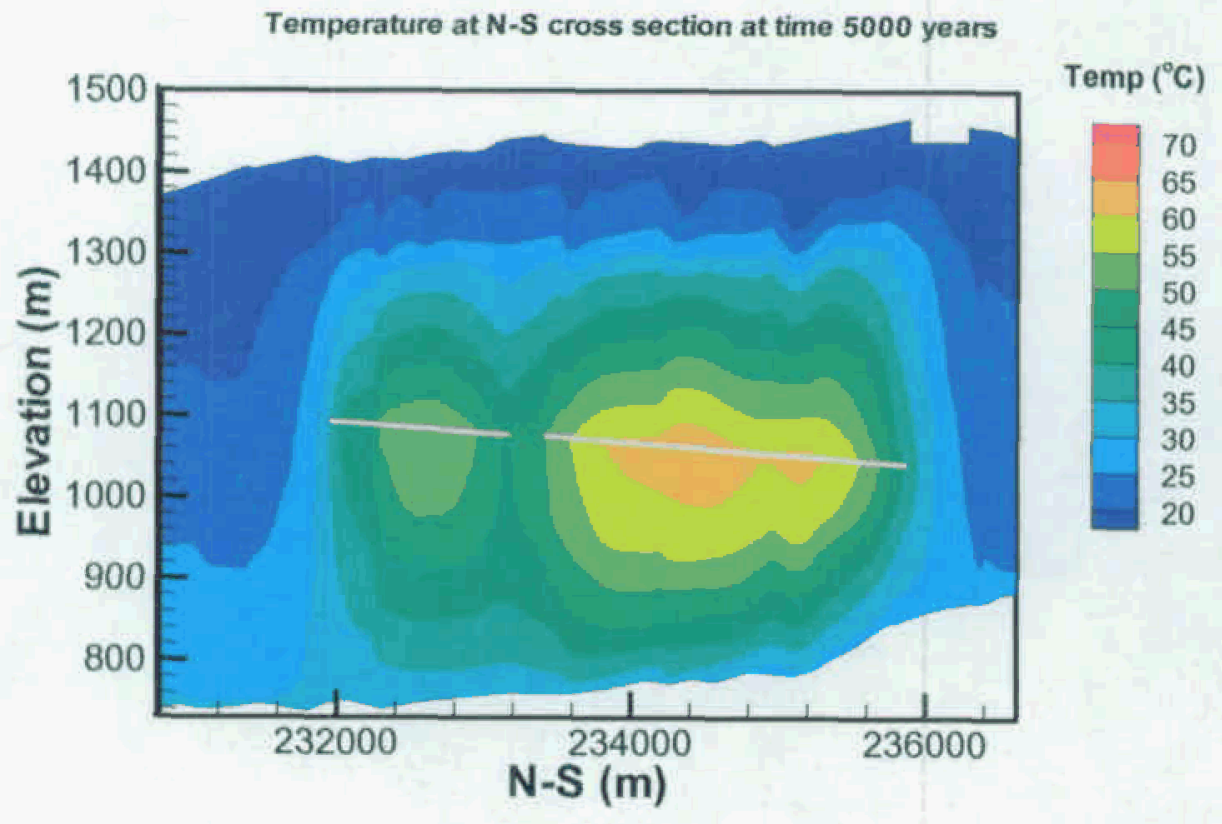

FIGURE 5A. Model-predicted temperature distribution at the n-s cross section at 5,000 years after nuclear waste emplacement (the base-case model with ventilation) 


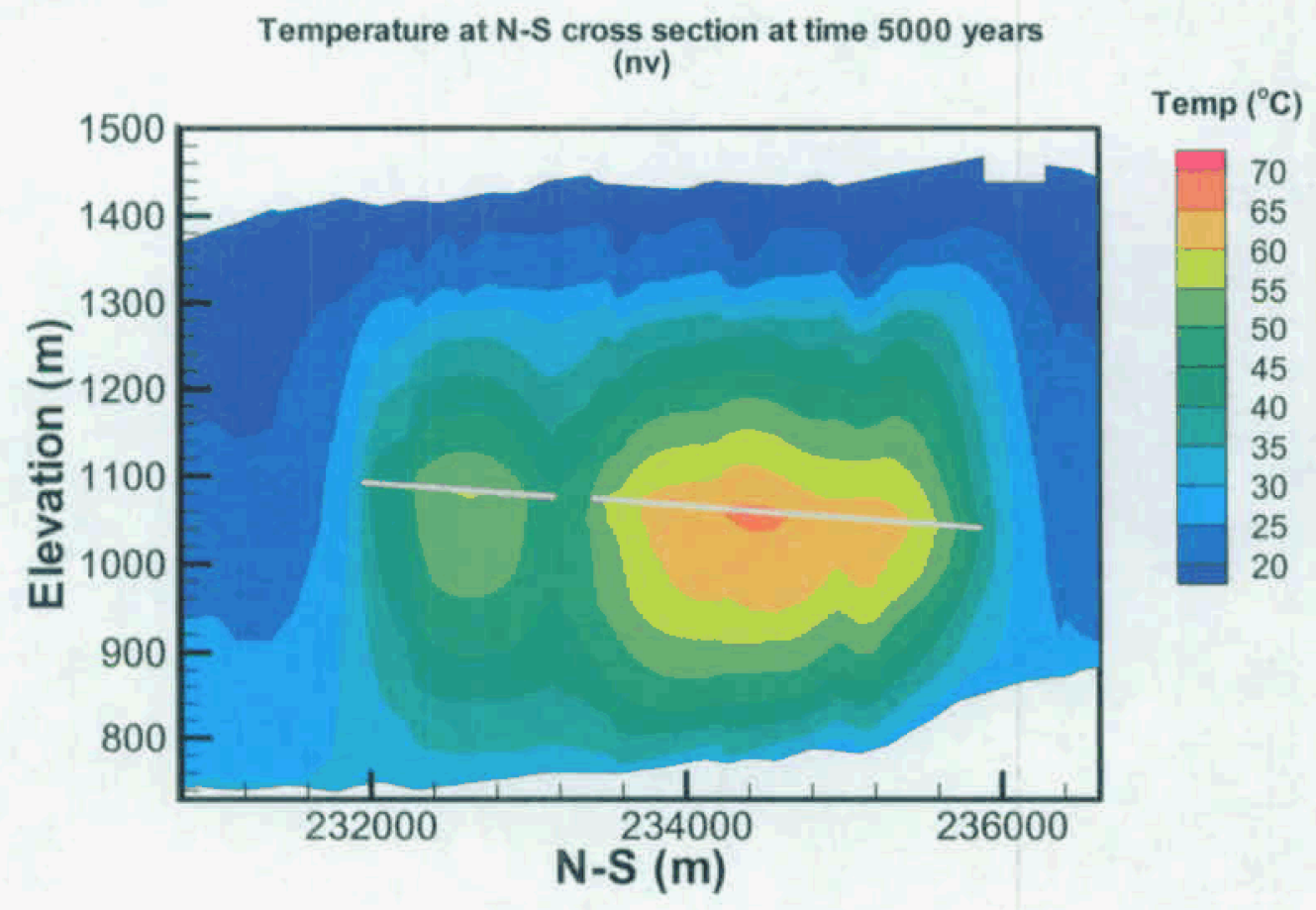

FIGURE 5B. Rock temperature distribution at the n-s cross section 5,000 years after waste emplacement as predicted by the 3-D TH model 


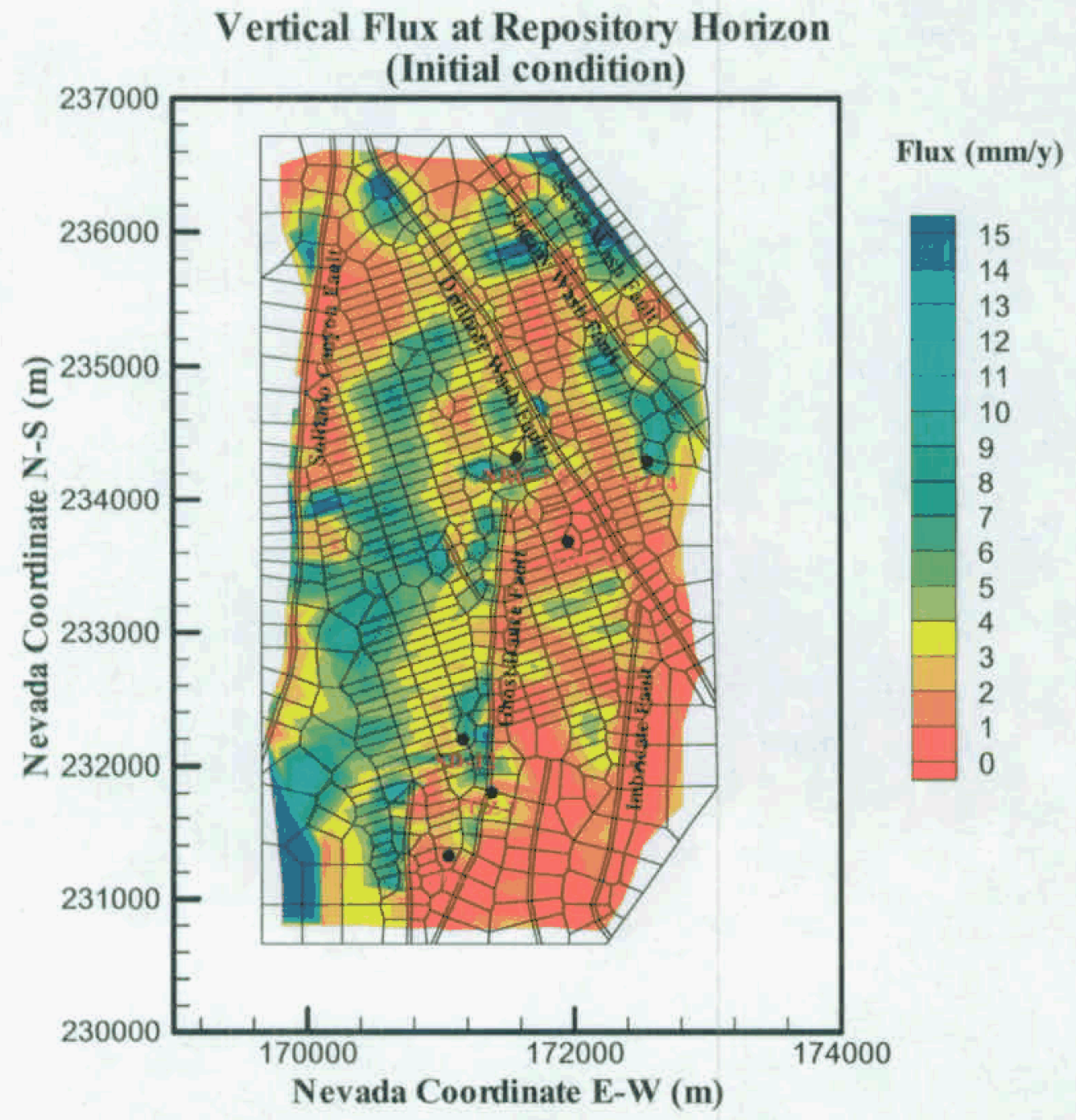

FIGURE 6A. Total vertical flux distribution at repository horizon under ambient conditions with the present-day, mean infiltration rates (Table 1) as predicted by the 3-D TH model 


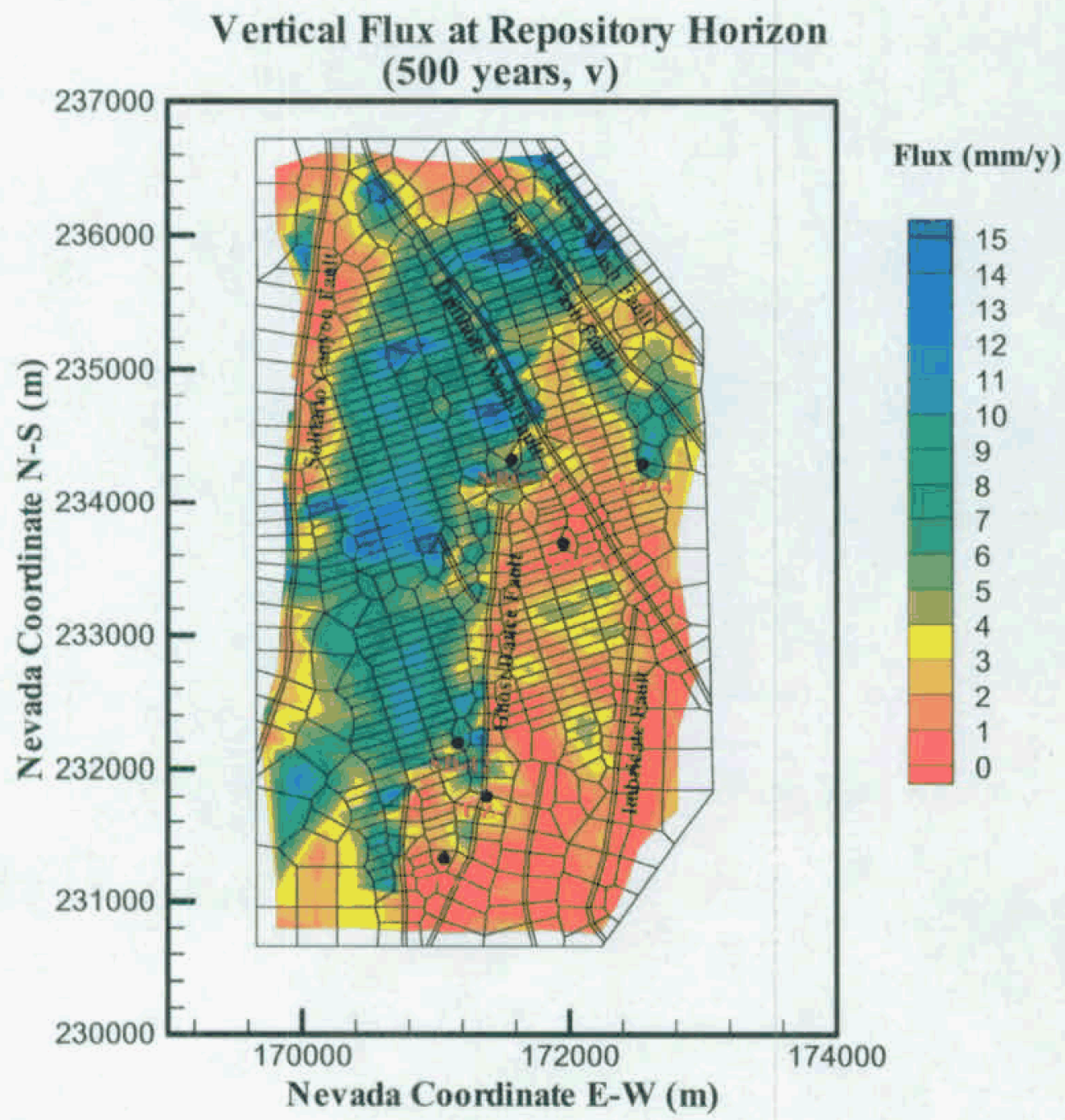

FIGURE 6B. Model-predicted total vertical flux distribution at repository horizon at 500 years after nuclear waste emplacement (the base-case model with ventilation) 


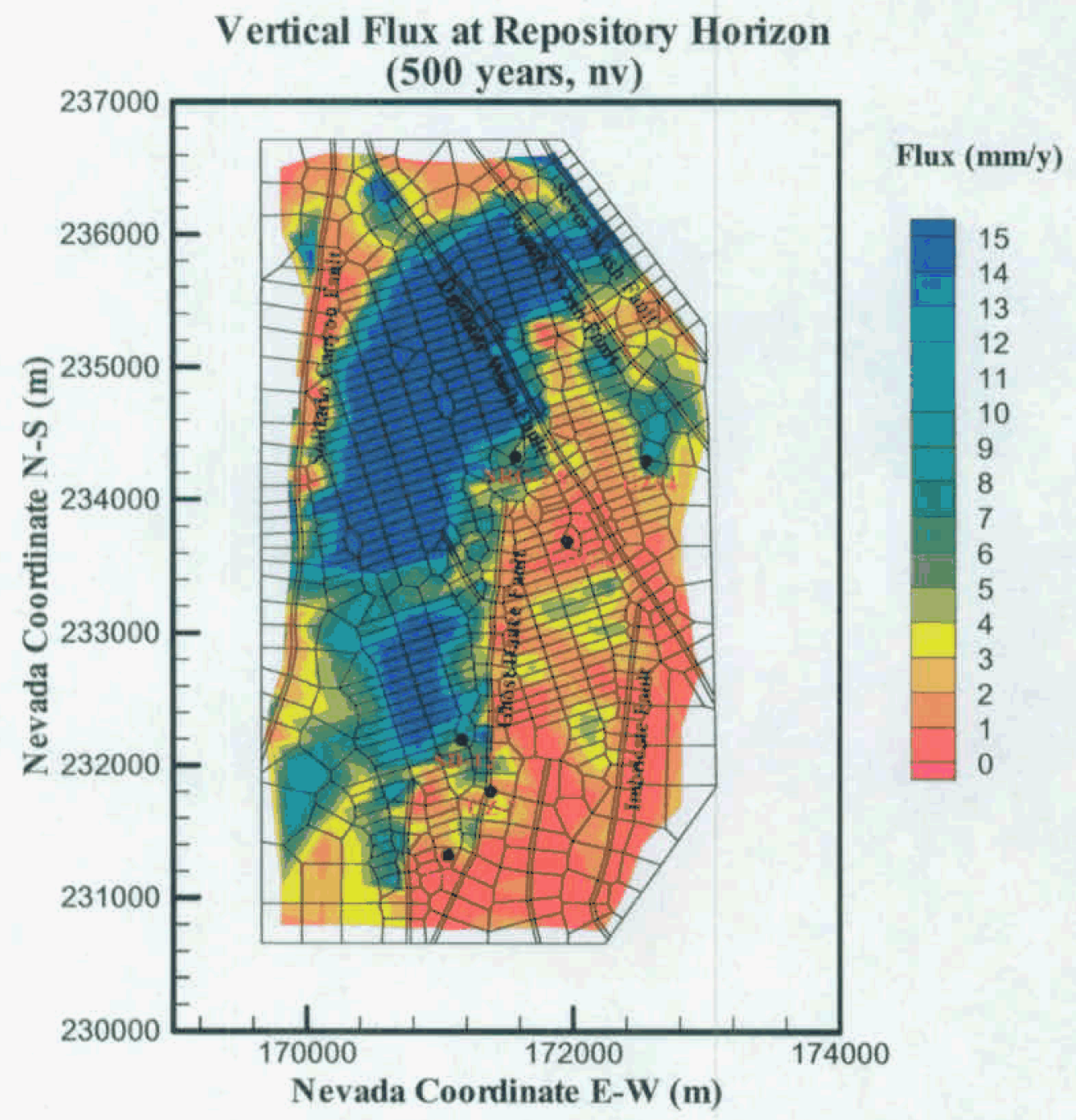

FIGURE 6C. Total vertical flux distribution at repository horizon 500 years after waste emplacement as predicted by the 3-D TH model without ventilation 